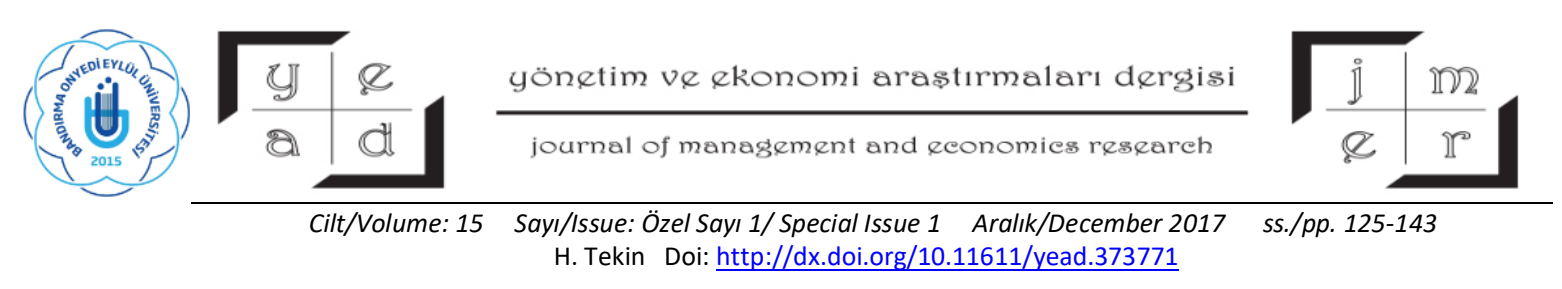

\title{
THE ROLE OF INSTITUTIONS IN DETERMINING SAVING RATES: CASE STUDY FROM TURKEY ${ }^{1}$
}

\section{Hüsnü TEKİN*}

\begin{abstract}
There exist numerous factors affecting saving rates in an economy such as demographics factors, economic factors as well as institutional factors. Therefore, the role of the institutions that we focus on in this paper is extremely critical for savings rates in an economy and so, economic growth.

For Turkey, despite of the fact that the role of financial system is incontrovertible in determining the savings, as an informal institution, the role of culture should also be considered as one of the determinants of savings rates since it has direct or indirect impact on almost all variables determining saving rates. In fact, we see that relatively lower labor force participation rate for females and the lower trust index in Turkey, which they have been influenced by the cultural structure of society in Turkey, somehow matter in determining saving rates in Turkey.

Accordingly, the relatively low savings rate in Turkish Economy reveals that the Turkish economy needs some measures to increase this lower rate. However, while some of these measures should be taken in the short-run, some should not, as in the case of cultural structure.
\end{abstract}

Key Words: Institutions, Saving Rates, Banking, Culture

JEL Classification: Z1, G2, G4

\section{KURUMLARIN TASARRUF ORANLARINI BELİRLEMEDEKİ ROLÜ: TÜRKIYYE ÖRNEĞİ}

\section{ÖZ}

Bir ekonomide tasarruf oranlarının belirlenmesinde demografik faktörler, ekonomik faktörler ve kurumsal faktörler gibi bir çok etken vardır. Dolayısıyla bu çalışmada ele aldı̆̆ımız kurumsal

\footnotetext{
${ }^{1}$ The first draft of this paper is presented ICOAEF 2017 conferance on 06-07 December 2017

* $\mathrm{PhD}$ Candidate at Islamic Economics and Finance Department of Istanbul University, Istanbul Turkey, husnu.tekin@hazine.gov.tr
} 
Yönetim ve Ekonomi Araștırmaları Dergisi / Journal of Management and Economics Research

Cilt/Volume: 15 Sayı/Issue: Özel Sayı 1/Special Issue 1 Aralık/December 2017 ss./pp. 125-143

H. Tekin Doi: http://dx.doi.org/10.11611/yead.373771

faktörler tasarruf oranlarını belirlenmesinde ve dolayıslyla iktisadi büyüme anlamında oldukça önemlidir.

Türkiye ekonomisi özelinde, tasarruf oranlarının belirlenmesinde finansal kurumların etkisinin yanı sıra, tasarruf oranlarının belirlenmesinde etken olan parametreleri doğrudan veya dolaylı olarak etkileyen ve bir informel kurum niteliğindeki kültürel yapının etkisinin de göz önüne alınması gerektiği açıktır. Gerçekten, Türkiye özelinde gerek kadınların işgücüne katılım oranlarının görece düşük olması, gerekse toplumdaki güven endeksinin nispeten düşük olasının Türkiye'de dolaylı olarak da olsa bir şekilde tasarruf oranlarının belirlenmesinde olumsuz bir etkisinin olduğunu görmekteyiz.

Bu kapsamda, benzer ülkelerle klyaslandı̆̆ında düşük tasarruf oranlarına sahip olan Türkiye'nin söz konusu oranları yükseltmek için çeşitli tedbirler alması gerektiği ortadadır. Ancak, şunu da ifade etmek gerekir ki bu tedbirlerden bazıları kısa dönemde çeşitli düzenlemelerle alınabilecek tedbirler iken, özellikle kültürel yapının değiştirilmesini öngören bazı tedbirler uzun vadeli olarak sonuçlarını vermeye başlayacaktır.

Anahtar Kelimeler: Kurumlar, Tasarruf Oranları, Bankacılık, Kültürel Yapı

Jel Sinıflandirması: Z1, G2, G4

\section{INTRODUCTION}

There have been numerous studies regarding saving rates in the economic literature. It is considered one of the fundamental sources of sustainable growth for countries. Therefore, it is worth examining the determinants of saving rates in an economy. Although it is really complex to determine the components of saving rates in an economy, economists suggest that these components may be divided into three main categories: demographic factors, economic factors and institutional factors. While some of these determinants of saving rates are difficult to influence by policies, at least in the short run, such as the saving behavior of individuals or existing cultural ideas related to the saving habits of a society, some determinants, such as inflation rates, interest rates, and taxes, are policy variables. ${ }^{2}$

Since assessing the all components of savings in a single paper is a huge task, considering the scope of this paper, we will restrict this study as follows. First, we will focus on the overall effect of institutions on savings rates and will look more closely at interactions between financial institutions. Secondly, because we believe that explaining the relatively low saving rates of Turkey with only

\footnotetext{
${ }^{2}$ Zee H., Tanzi V. (1998), “ Taxation and Household Saving Rate: Evidence from OECD countries”, IMF Working Paper
} 
Yönetim ve Ekonomi Araștırmaları Dergisi / Journal of Management and Economics Research

Cilt/Volume: 15 Sayı/Issue: Özel Sayı 1/Special Issue 1 Aralık/December 2017 ss./pp. 125-143

H. Tekin Doi: $\underline{\text { http://dx.doi.org/10.11611/yead.373771 }}$

financial institutions is not enough, we will also assess the impact of broader cultural structures in Turkey on saving rates, focusing specifically on the impact of culture on gender differences in economic activities and investor behavior as determinants of savings rates in Turkey.

\section{SAVING RATES IN TURKEY}

\section{A. Saving Rates and the Main Determinants of Domestic Saving Rates in Turkey}

\section{Savings in General}

In the theory of economics, saving is, in general, defined as a process of setting aside a portion of current income for future use, or as the resources accumulated in this way over a given period of time. According to major growth theories, savings is one of the fundamental determinants of economic growth in the economy, and there exists a strong correlation between savings and economic growth, although the direction of causality is ambiguous.

In countries all over the world, saving rates have displayed considerable variation from one country to another over time. For example, the savings rate in emerging Asia, as a cohort, is more than $40 \%$ of GDP. ${ }^{3}$ (Ferruci \& Mirales, 2007) When we look at the last four decades, we see a divergence process in the saving rates of countries in the world: steadily rising in East Asia, stagnated in Latin America, and falling in Sub-Saharan Africa, and in each region closely overlapping the growth performance. $^{4}$

Therefore, investigating possible answers to the question of "what are the main determinants of saving rates in an economy?" has been one of the most popular studies of economics. Possible reasons effecting saving rates may be collected under three main groups: demographic factors, macroeconomic factors, and institutional factors (Ferruci \& Mirales, 2007). ${ }^{5}$

Even casual observation suggests the link between abovementioned factors and savings. For instance, the existence of a healthy financial system is extremely important for savings since it facilitates the availability of saving instruments for savers. However, on the other hand, sometimes it could have the reverse effect on savings rates since it removes borrowing constraints, thereby increasing current consumption and reducing saving rates, as in the case of Turkey after the 2001 crises. In Turkey, with improvements in the macroeconomic environment due to the measures following the financial crises in

\footnotetext{
${ }^{3}$ Ferruci G.i, Miralles C., " Saving Behavior and Global Imbalances: The role of emerging market economies" European Central Bank Working Paper Series No 842, December 2007

${ }^{4}$ Loayza N., Schmidt-Hebbel K., Serven L., "What Drives Private Saving Across the World" Central Bank of Chile, Working Papers, November 1999

${ }^{5}$ According to the ILO (International labor organization), working age is 15-64
} 
Yönetim ve Ekonomi Araștırmaları Dergisi / Journal of Management and Economics Research Cilt/Volume: 15 Sayı/Issue: Özel Sayı 1/Special Issue 1 Aralık/December 2017 ss./pp. 125-143 H. Tekin Doi: http://dx.doi.org/10.11611/yead.373771

2001 in both financial sectors and fiscal discipline, credit facilities have grown due to the decline in interest rates, leading to an increase in the consumption of households.

(2) Savings in Turkey

Figure I: Total Savings \% of GNI, Turkey and Take-off Countries ${ }^{6}$

(Averages of Relevant Period)



Source: WDI

As seen in the figure above, although Turkey is in the upper-middle income group according to the World Bank classification, saving rates in Turkey are relatively lower than the take-off countries.

Table I: Saving and Current Account Balance \% of GDP in Turkey

\begin{tabular}{|c|c|c|c|c|c|c|c|c|c|c|c|c|c|c|}
\hline & 2001 & 2002 & 2003 & 2004 & 2005 & 2006 & 2007 & 2008 & 2009 & 2010 & 2011 & 2012 & $2013 *$ & $2014^{*}$ \\
\hline $\begin{array}{c}\text { Public Saving } \\
\text { Gap }\end{array}$ & -11.2 & -9.76 & -7.8 & -4.2 & -1.2 & 0.53 & -1.5 & -2.5 & -5.3 & -2.4 & -1.6 & -2.2 & -1.9 & -1.5 \\
\hline $\begin{array}{c}\text { Private } \\
\text { Saving Gap }\end{array}$ & 14.11 & 10.3 & 5.29 & 0.37 & -3.3 & -6.4 & -4.4 & -2.8 & 3.26 & -3.9 & -7.6 & -5.6 & -5.4 & -5.3 \\
\hline $\begin{array}{c}\text { Total Saving } \\
\text { Gap/CAD }\end{array}$ & 2.9 & 0.57 & -2.5 & -3.8 & -4.4 & -5.8 & -5.9 & -5.3 & -2.1 & -6.3 & -9.2 & -7.8 & -7.3 & -6.8
\end{tabular}

Source: Ministry of Development, * Medium term program forecast

\footnotetext{
${ }^{6}$ Take-off countries are defined as developing countries that achieved high and sustained growth rates in 19802008. The group of take-off countries includes Chile, China, Hong Kong SAR, China, Indonesia, Korea, Rep., Malaysia, Mauritius, Singapore and Thailand. (WB, 2011)
} 
Yönetim ve Ekonomi Araștırmaları Dergisi / Journal of Management and Economics Research

Cilt/Volume: 15 Sayı/Issue: Özel Sayı 1/Special Issue 1 Aralık/December 2017 ss./pp. 125-143

H. Tekin Doi: http://dx.doi.org/10.11611/yead.373771

Table I illustrates the composition of the saving rate between 2001-2014. The main reason for the low saving rate in Turkey is the low level of private savings. Accordingly, in this paper, the focus is on factors affecting the private savings rate.

\section{THE LINKAGE BETWEEN FINANCILA INSTITUTIONS AND SAVING RATES IN}

\section{TURKEY}

\section{B. Institutions in General}

\section{Definition}

Though there exist various definitions for the term "institution," the main common points of these definitions are rules, beliefs, norms, and organizations. Greif (2006), for example, defines institutions as "a system of rules, beliefs, norms, and organizations that together generate a regularity of social behavior." Institution may also be generally defined as "the rules of the play in a society" (North, 1990)

\section{The Role of Institutions in Determining Savings}

There are a great number of studies showing the influence of institutions on the saving behavior of individuals in a society. Sherraden (1991), for example, argues that asset accumulation is primarily the result of institutionalized mechanisms involving explicit connections, rules, incentives, and subsidies. On the other hand, people with higher original tax rates tend to participate in tax-deferred savings programs (Joulfaian and Richardson, 2001). Moreover, saving behaviors may differ depending on income level. The poor, for example, do not have access or receive the same incentives from institutions that promote and subsidize asset accumulation. They are also less likely to have jobs with pension benefits, and even if they do, they receive few or no subsidies because they have zero or low marginal tax rates and tax benefits that are not refundable. ${ }^{8}$

According to a cross-country estimation based upon estimations between 1998-2008 by Loayza, Schmidt, and Serven (2000), the main determinants of private savings in Turkey are the real interest rate, the gross private disposable income, the young age dependence ratio and inflation. Accordingly, when we consider the impacts of institutions on these variables, we may conclude that institutions such as financial institutions, and culture are directly or indirectly related to savings in Turkey. For example,

\footnotetext{
${ }^{7}$ Greif A., "Institutions and the Path to the Modern Economy: Lesson from Medieval Trade" Cambridge University Press, 2006

${ }^{8}$ Altug Sumru, Filiztekin Alpay, Pamuk Sevket, "The Sources of Long-term Economic Growth for Turkey, 1880-2005”, CEPR Discussion Paper Series, September 2007
} 
Yönetim ve Ekonomi Araștırmaları Dergisi / Journal of Management and Economics Research

Cilt/Volume: 15 Sayı/Issue: Özel Sayı 1/Special Issue 1 Aralık/December 2017 ss./pp. 125-143

H. Tekin Doi: $\underline{\text { http://dx.doi.org/10.11611/yead.373771 }}$

a relatively lower tax rate on income would theoretically lead to higher disposable income, and since individuals save some amount of disposable income, savings would increase.

According to one survey by Turkish Statistic Institution in 2008, roughly 67\% of households in Turkey save in the form of nonfinancial assets, $53.5 \%$ in their primary residence, $25.6 \%$ in vehicles, and the remaining $10.1 \%$ in other property, such as land. Only $30 \%$ of households reported that they have any type of financial assets. Because of a lack of necessary financial institutions, many women and even some men have participated in "gold days" or "currency days" "as a way of saving in Turkey. ${ }^{10}$

\section{Selected Institutions and their Relationship to Saving Rates in Turkey}

\section{(1) Possible Components of Saving Rates in Turkey}

As mentioned earlier, there exist multiple factors affecting savings rates in Turkey. These components may be grouped as social/demographic and economic components. Social/demographic components include those such as dependency ratios, age distribution of households, rural-urban ratios, the labor force participation rate, and education level. We may state economic components as improved prospects, access to credit, inflation, interest rates, exchange rates, terms of trade and others. However, considering the scope of this paper, we will focus on the role of just two: financial institutions and cultural structure as an informal institution. After assessing the role of financial institutions, I will analyze in the following section the role of cultural in Turkey in determining savings rates, since any analyses trying to explain the saving behavior of individuals would likely fail if the role of culture is not considered.

\section{(2) The Role of Financial Institutions in Determining Savings Rate}

Financial institutions allow individuals to smooth consumption and invest. Therefore, improving the financial system may have two advantages in terms of savings. The first is for individuals who are already using the financial system. Improvement in the system should lower the cost of using it. The second advantage is for individuals who have no access to the financial system.

In addition to providing access, institutions shape defaults, behavior and provide implicit planning, three actions that can impact the saving behavior of individuals. Consider two individuals, one who has a bank saving account and another who does not. While the one who has a bank saving account will

\footnotetext{
${ }^{9}$ These two activities were used a way to save in Turkey in 1980s and 1990s. Firstly women started to organize these meetings to encourage themselves to save due to the high inflation rate in Turkey in 1980s and 1990s. Then even between men these days were so popular. For instance, they form a group and meet once a month and every member of the group gives a quarter gold coin to a member and this rotation goes on until every member benefits this.

${ }^{10}$ The World Bank, Sustaining High Growth: The Role of Domestic Savings", Turkey Country Economic Memorandum
} 
Yönetim ve Ekonomi Arastırmaları Dergisi / Journal of Management and Economics Research

Cilt/Volume: 15 Sayı/Issue: Özel Sayı 1/Special Issue 1 Aralık/December 2017 ss./pp. 125-143

H. Tekin Doi: http://dx.doi.org/10.11611/yead.373771

tend to spend less than the other, since the one with the account needs to withdraw money from this account, for the latter, cash is more available to use. Furthermore, financial institutions provide safety and control to savings. Unbanked individuals use alternative financial institutions, which are generally more costly than banking systems, or their relatives or friends to meet their emergency needs. ${ }^{11}$

Among the many factors that influence the size of capital markets, institutions appear to be the strongest. The size of financial markets varies across countries. Herger, Hodler and Lobsiger (2007) tried to find the reason for this difference across countries by examining the culture, institutions, geography, and colonial history of the countries. They found that trade openness and institutions that constrain the political elite from expropriating financiers exhibit a strong positive effect on the size of capital markets in a country. ${ }^{12}$

\section{(3) The Financial System in Turkey}

Although there has been significant development in the number of non-bank financial instruments such as finance and leasing companies and active security markets, commercial banks have continued to dominate the financial system in the world as well as in Turkey. ${ }^{13}$ In terms of major financial assets in Turkey, deposits in Turkish Lira and foreign currency, gold, under the pillow savings, which are out of the system, mutual funds, and fixed-income securities issued by the government, Eurobonds, stocks, shares and private pension schemes make up the country's main financial assets. Nonfinancial assets include primary residence, other residential property, other real estate and land/farm, business, vehicles and other nonfinancial assets. Figure II demonstrates the financial asset composition of households as of the end of 2010. Deposits constitute the biggest share, at $67 \%$. A relatively high return on bank deposits helps explain their predominance in household financial assets. ${ }^{14}$

\footnotetext{
${ }^{11}$ Shafir E., Mullainnathan S., "Savings Policy and Decision-making in Low-Income Households", Innovation for Poverty Action, 2009http://battlenations.wikia.com/wiki/Category:Unreleased_content

${ }^{12}$ Herger N., Hodler R., Lobsiger M., "What Determines Financial Development? Culture Institutions or Trade", World Trade Institute, February, 2007

${ }^{13}$ Vittas D., Skully M., “Overview of Contractual Savings Institutions”, the World Bank, March 1991

${ }^{14}$ www.turkstat.gov.tr accessed on October 20, 2013
} 
Yönetim ve Ekonomi Araștırmaları Dergisi / Journal of Management and Economics Research

Cilt/Volume: 15 Sayı/Issue: Özel Sayı 1/Special Issue 1 Aralık/December 2017 ss./pp. 125-143

H. Tekin Doi: http://dx.doi.org/10.11611/yead.373771

Figure II: Financial Markets (International

Comparison, Percent of GDP, 2009)

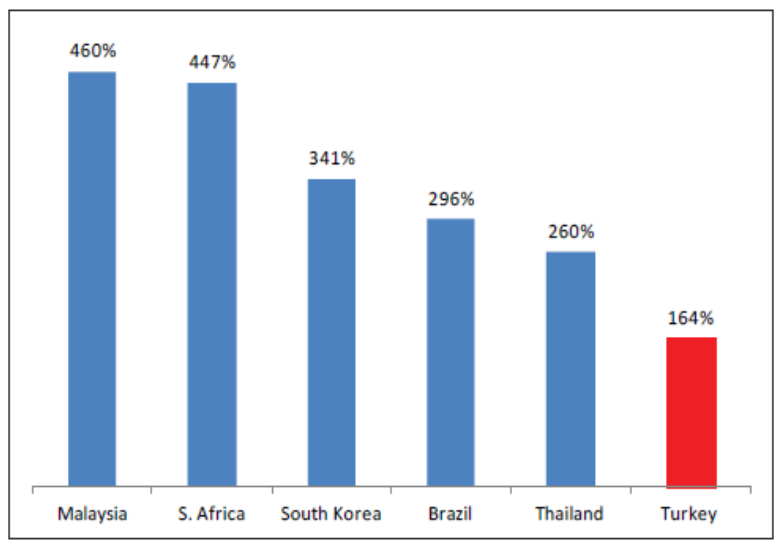

Source: WB, 2011
Figure III: Composition of Turkish Household

Financial Assets, 2010

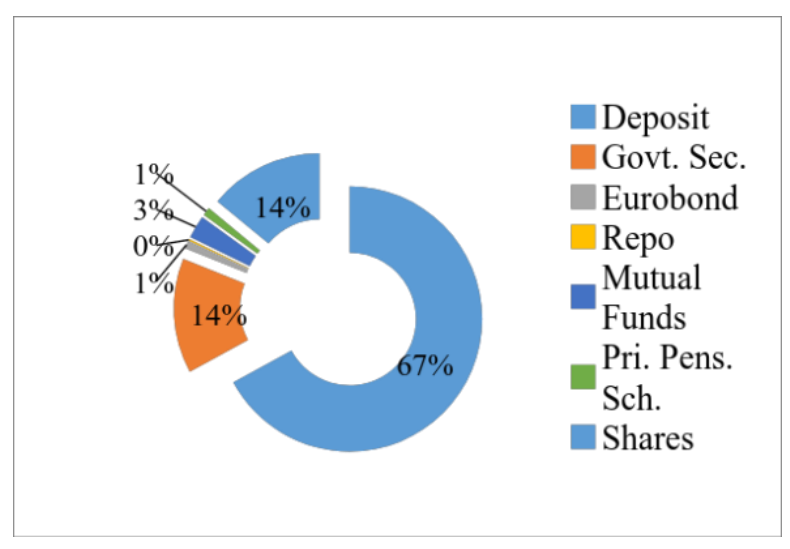

Source: CBRT

Even so, the size of the financial markets in Turkey has increased more than fourfold between 2002-2013, from TL 316 billion at the end of 2002 to TL 1.528 billion by the end of June 2013. ${ }^{15}$ Moreover, Turkey has also taken steps to build its corporate bond market and stimulate growth of its stock markets; hence, growth in both would be greatly facilitated if the domestic investor base was expanded at the same time (WB, 2011).

In general, we may state that the Turkish financial market is dominated by the banking system. Banks account for roughly $88 \%$ of the total financial sector. The remaining $12 \%$ is nonbank institutions.

The stock market is one of the other options for investors seeking investment instruments in financial market. Even though the stock market in Turkey has grown rapidly, it is still small compared to similar countries, such as Malaysia and Thailand. Total Istanbul Stock Exchange (ISE) capitalization increased 600\% between 2002 and 2010, reaching approximately 38\% of GDP. Moreover, foreign investors dominate the IFS, accounting for $60 \%$ of market capitalization. The ISE-100 index increased almost $200 \%$ between 3003-2013, which is higher than the increase in the inflations rate, which was $125 \%$ for the same period. ${ }^{16}$ This means that ISE equities were a profitable financial instruments for investors. Despite of the all these positive developments in the stock market, stock markets have never been a major source of funds for the corporate sector in Turkey. It is possible to reckon highly

\footnotetext{
${ }^{15}$ ttp://www.bddk.org.tr/WebSitesi/turkce/Raporlar/TBSGG/12277tbs_genel_gorunumu_haziran_2013.pd

${ }^{16}$ www.tcmb.gov.tr, www.borsaistanbul.com accessed November 23, 2013
} 
Yönetim ve Ekonomi Araștırmaları Dergisi / Journal of Management and Economics Research

Cilt/Volume: 15 Sayı/Issue: Özel Sayı 1/Special Issue 1 Aralık/December 2017 ss./pp. 125-143

H. Tekin Doi: http://dx.doi.org/10.11611/yead.373771

concentrated corporate ownership, taxing dividends, and lack of quasi-equity instruments as convertible bonds and preference shares as the reasons for the slow access of companies to ISE.

Figure IV: Interest Rates (\%)

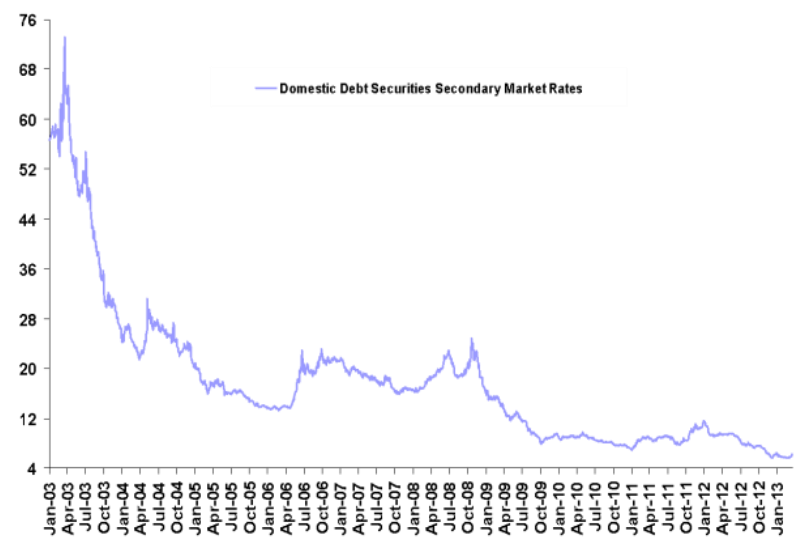

Source: Undersecretariat of Treasury
Figure V: ISE 100 Index

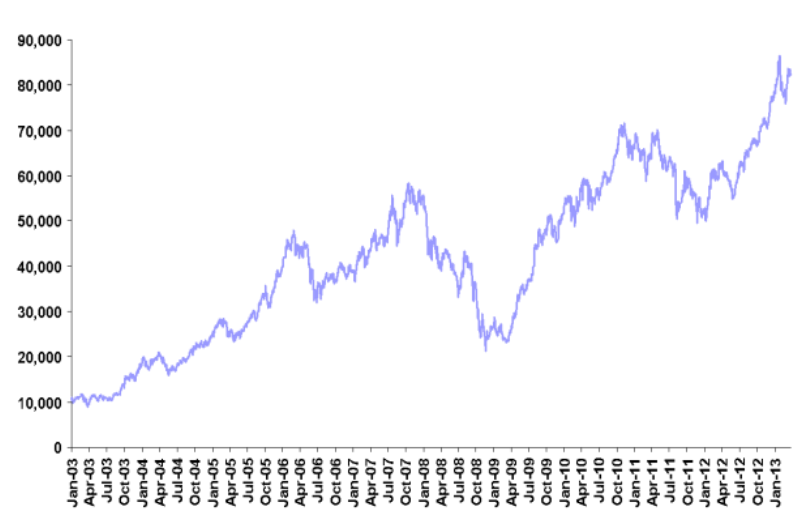

Source: ISE

On the other hand, the corporate market bond in Turkey is relatively underdeveloped. It accounts for less than $1 \%$ of financial markets in 2013. Generating an active corporate market requires stable macro-economic conditions such as a low inflation rate and a low interest rate. Considering the unstable macroeconomic conditions in 1990s in Turkey, it is not surprising that the corporate market is undeveloped in Turkey. In the case of high inflation, since the government is the major bond seller to finance its growing deficits, this has a caused crowding effect for the private sector. In fact, the Turkish corporate market was relatively active in the 1990s, although the majority of these bonds were issued by the banks as bank bills. With the 1994 economic crises in Turkey, economic indicators were distorted, hyper-inflation rates showed up and the fiscal deficit reached to very high levels. As a result, the government took measures that strongly crowded out the domestic borrowing market and the bond market eroded. Additionally, the government gave a tax advantage to governments bonds against corporate bonds to make borrowing from the domestic market easier. Corporate bonds were subject to $10 \%$ withholding tax on interest gains but the government bonds were subject to $0 \%$. This situation continued until the 2000s. Even though there were some improvements in 2007 and 2010 in the corporate bond market, it is still relatively underdeveloped compared to the top emerging corporate bond markets. 
Yönetim ve Ekonomi Arastırmaları Dergisi / Journal of Management and Economics Research

Cilt/Volume: 15 Sayı/Issue: Özel Sayı 1/Special Issue 1 Aralık/December 2017 ss./pp. 125-143

H. Tekin Doi: http://dx.doi.org/10.11611/yead.373771

\section{INSTITUTIONS, CULTURE AND SAVING RATES IN TURKEY}

\section{Does Culture Matter in Determining Saving Rates?}

Before assessing the relations between culture and savings rate, it is critical to define the term "culture." Even though there is no agreed definition for this term, one may define culture as a body of a shared knowledge, understanding, and practice in a society. According to the Merriam Webster ${ }^{17}$ dictionary culture is "the integrated pattern of human knowledge, belief, and behavior, that depends on the capacity for learning and transmitting knowledge to succeeding generations" and "the customary beliefs, social norms, and material traits of a racial, religious, or social group; and the set of shared attitudes, values, and practices that characterized an institutions or organization."

Various studies have attempted to reveal the linkage between culture and economic outcomes over the last two decades (Guiso, Sapienza, Zingales, 2005; Algan and Cahuc 2006; Ichino and Maggi 2000; Guilliano 2007; Greif 1994, 2005). ${ }^{18}$ Most of them have agreed that culture somehow matters in determining the economic development of a country. Gerard and Grodnichenko (2010) found that there is a strong correlation between culture and long-run growth rates. According to the results of the study, while collectivism leads to relatively static efficiency gains, individualism leads to dynamic innovation effects. They argue that institutions play a significant role in stimulating innovation and hence, longrun economic growth, and that, culture affects not only social norms but also economic behavior such as propensity to save or to innovate. Additionally, they look at individualism, using the Hoftsrede index ${ }^{19}$ as a proxy. While not every country fits the model, the U.S., Australia and the E.U have a higher index, and corresponding higher economic growth, Turkey and Middle East countries have lower index values and growth rate.

Accordingly, there are a great deal of components in forming of a culture in a society, including historical experiences and religion, as well as the global geographical. In fact, historical experiences have important impacts on both an individual's and a society's beliefs and preferences. As shown by Alesinia and Fuchs-Schundeln (2007), for example, communism, as a historical experience, had a significant impact on the beliefs of the people who lived under it. According to their study, the individuals who lived in East Germany prior to reunification are more likely to favor government provision. Furthermore, Weber $(1930,1951)$ argued that the development of capitalism stem from the

\footnotetext{
${ }^{17}$ http://www.merriam-webster.com/ , accessed on December 2, 2013

18 Fernandez R., "Alfred Marshall Lecture Women, Work and Culture”, Journal of the European Economic Association, April =-May, 2007

19 This indexed, developed by Geert Hofstede. It describes the effects of a society's culture on the values of its members, and how these values relate to behavior, using a structure derived from factor analysis.
} 
Yönetim ve Ekonomi Araștırmaları Dergisi / Journal of Management and Economics Research

Cilt/Volume: 15 Sayı/Issue: Özel Sayı 1/Special Issue 1 Aralık/December 2017 ss./pp. 125-143

H. Tekin Doi: http://dx.doi.org/10.11611/yead.373771

protestant ethics in the West, which allowed protestants to develop the idea of pure business relationship. Greif (2006) emphasizes that different structure of the cultures lead to different kinds of institutions, as in the case of the Maghreb traders and the Genoese, and how institutions form the subsequent development path of these societies. While human capital is a well-known determinant of growth and development, according to a working paper by the Leibniz Information Center, early political institutions are the main reason for current economic performance differences of regions in Europa. ${ }^{20}$ Accordingly, they conclude that historical institutions have shaped the culture, and that culture is one of the main determinants of economic development.

Another way that culture is transmitted, through attitudes, is from parents to children. Alesina and Guiliano (2009) show that cultural proxy has explanatory power for in-country variation in political attitudes among individuals from different countries of ancestry. They also found that the strength of family ties matter for labor market outcomes as well as the level of institutional development in a country. Education is also a main pathway for cultural impact on economic behavior. They argue that the main root of the financial crises in 2008 was the low saving rates in developed countries especially in U.S., and that cultural variables, particularly a level of uncertainty avoidance and collectivism, have a significant effect on the level of savings. As the level of uncertainty avoidance increases, the level of national savings increases. Furthermore, the more collectivist the society, the higher the saving rate.

Culture appears to both directly and indirectly affect the saving rates of an economy. For instance, culture may have impact on economical behavior, such as the decision to be self-employed rather than working for another, the development of trust between employees and the entry choices of multinational firms into a country. Lunt and Livingston (1991) found that non-savers tend to not tell friends or relatives about their financial situations, keeping their financial position private. Therefore, they suggest that social support is related to saving. By talking to their relatives and friends, savers receive social support for their approach to finances and information on how to save or how to use the financial system to save. ${ }^{21}$

In the particular case of Turkey, although there are many variables that could be explored in assessing the relationship between culture and saving rates, I will limited my paper to only two main components, which are gender differences and investor behaviors.

\footnotetext{
${ }^{20}$ Leibniz Information Center, "Culture and Institutions: economic development in the regions of Europe" CESifo working papers, No. 1492

${ }^{21}$ Shoham A., Vrontis D., "The role of cultural attributes in savings rates", Cross Cultural management, 19.3.2012, 304-314
} 
Yönetim ve Ekonomi Arastırmaları Dergisi / Journal of Management and Economics Research

Cilt/Volume: 15 Sayı/Issue: Özel Sayı 1/Special Issue 1 Aralık/December 2017 ss./pp. 125-143

H. Tekin Doi: http://dx.doi.org/10.11611/yead.373771

\section{(1) The Role of Culture in Gender Differences in Economic Activity}

There exist considerable variation in the gender gap $\mathrm{p}^{22}$ in labor force participation rates (LFPR) across countries. This gap is 89.4 in Afghanistan, 2.2 points in Sweden. Possible explanations for this variation include differences in human capital and in labor market institutions across countries. However, we may include "cultural" factors as one of the potential reasons. Family structure, and the role of women's in the market, differs from country to country. The education levels of woman and fertility choices also affect the level of LFPR of females. Antecol (2000) examined the reasons for the gender gap in terms of LFPR in the U.S by using data for second-generation U.S. women. Over half of the overall variation in gender gap for first generation immigrants can be attributed the gender gap of the home country. For the second generation and subsequent generations, this connection between the gender gap of the home country gets smaller. Therefore, it is clear that cultural factors play a role in explaining why some groups of women work more, relative to men, than others. ${ }^{23}$

Differences in the utility function between men and women can also be explained by culture. In general, women are more likely to spend income on health, education, and food for children, while men, in general, and spend larger proportions of income on luxury goods, such as cigarettes, alcohol, and gambling (Guyer, 1980; Neuhauser, 1989, Thomas, 1992). Moreover, the decision making process in the allocation of the resources of the household depends on the bargaining power of adults. For instance, in South Korea, where the young women make up the main workforce for export industries, Kim (1997) found that among their highest priorities in decisions on how to allocate earnings were saving for a dowry and financing their siblings' education. Women indicate that to achieve this goal, given their low salaries, they were compelled to skip meals, cut back on other necessities, and live in crowded conditions. This finding suggests the strong impact of social norms on consumption behavior and by extension, saving behavior.

The impact of culture on gender difference in LFPRs may also be observed in Turkey. The figure VI shows the labor force participation rate for males and females in Turkey.

\footnotetext{
${ }^{22}$ Gender gap means labor force participation rate of male minus LFPR of female.

${ }^{23}$ Antecol H., "An Examination of cross-country differences in the gender gap in labor force participation rate", Labor Economics 7, February, 2000
} 
Yönetim ve Ekonomi Araștırmaları Dergisi / Journal of Management and Economics Research

Cilt/Volume: 15 Sayı/Issue: Özel Sayı 1/Special Issue 1 Aralık/December 2017 ss./pp. 125-143

H. Tekin Doi: http://dx.doi.org/10.11611/yead.373771

Figure VI: Labor Participation Rates

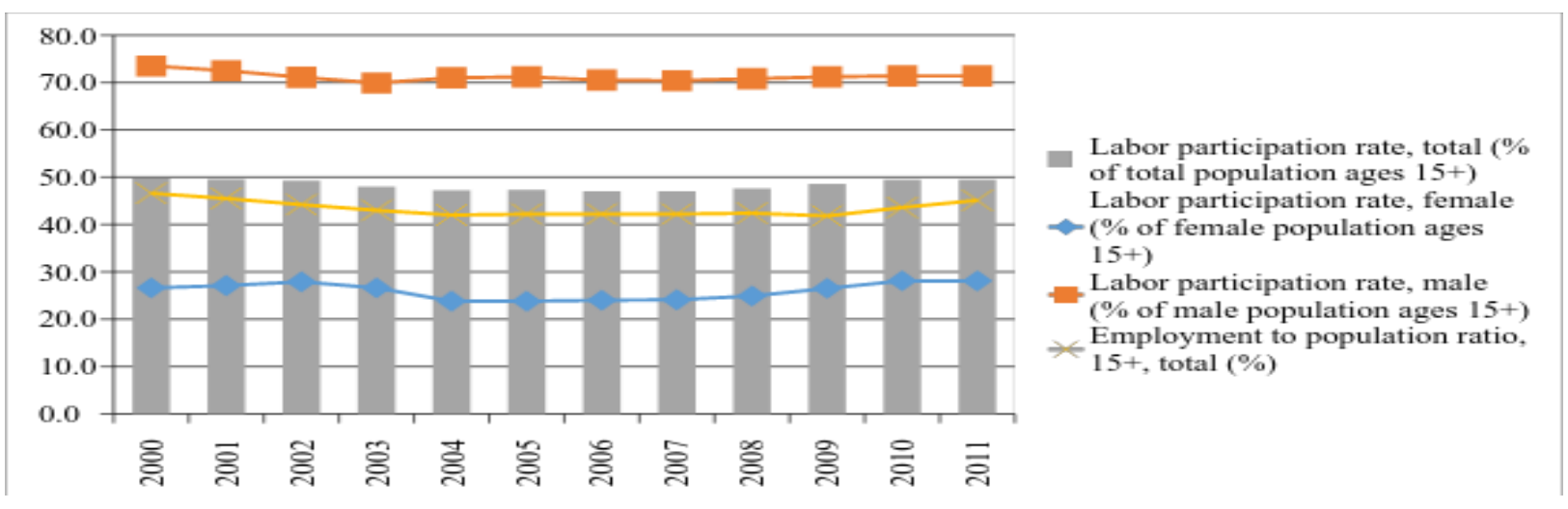

Source: WDI

While the LFPR for males is above 70\%, which is not too different from the LFPR of OECD average $80 \%$ as of 2011 , there is a significant difference in terms of LFPR for females. As of 2011, whereas the LFPR for females in Turkey is less than 30\%, the OECD average is roughly 65\%. There are many reasons for this relatively low LFPR for females in Turkey, such as the continuing transition from agricultural to service and manufacturing, the low education level of females and the overall role of females in economic life. The data about the LFPR for females illustrates that the role of females in the labor market are lower than that of males in the Turkey in general, and we can see the strength of this variance by assessing the changes in LFPR for females during times economic crises, 2001, 2009 and 2011. During economic crises, since there is a probability of losing jobs for males, women tend to want to work, and the LFPR for females increases. On the other hand, the similar ration in terms of LFPR for male and female in higher education level points out the significance of education level in determining LFPR of female in Turkey.

\section{(2) The Role of Culture in Saver Behavior}

Culture matters in determining the behavior of individuals in the saving process and is influenced by their culture and past experiences during the saving decision. Statman (2008) investigates the role of cultural differences on corruption perception among countries. The author surveyed people in various countries asking if the situation in a story (of potential insider trading) was fair or not. ${ }^{24}$ While $56 \%$ of Turkish people said it was fair, $5 \%$ of people in the U.S. said it was fair. Accordingly, we may conclude that social norms and perceptions of fairness vary from country to country and affect saving

\footnotetext{
${ }^{24}$ The author asked people to comment on the following: "A lawyer overheard a conversation between another lawyer and his customer. A company will offer to pay $\$ 120$ for its shares. Therefore, the lawyer bought that company's share at $\$ 70 . "$
} 
Yönetim ve Ekonomi Araștırmaları Dergisi / Journal of Management and Economics Research

Cilt/Volume: 15 Sayı/Issue: Özel Sayı 1/Special Issue 1 Aralık/December 2017 ss./pp. 125-143

H. Tekin Doi: http://dx.doi.org/10.11611/yead.373771

decisions of individuals in these countries. This difference in perceptions about the fairness of an action may be one of the reasons accounting or the difference in risk premium in these two countries. In this survey, the author tried to find out the role of culture in financial decisions in 22 countries. According to their findings, whereas people in China and Vietnam were the most willing to take risk, Germany and Switzerland were the least willing. Additionally, poor people were found to be more willing to take risk than rich people. Because of this willingness, they buy more lottery tickets relatively to their income level than riches. Therefore, one may conclude that low-income countries are more willing to take risk than developed countries. Other findings in the article that demonstrate the role of culture on savings decisions include the finding that people in collectivistic countries may afford to take more risk because their in-groups provide downside protection and that trusting people are also willing to take more risks. ${ }^{25}$

\section{Figure VII: Relationship between Trust and GDP per capita}

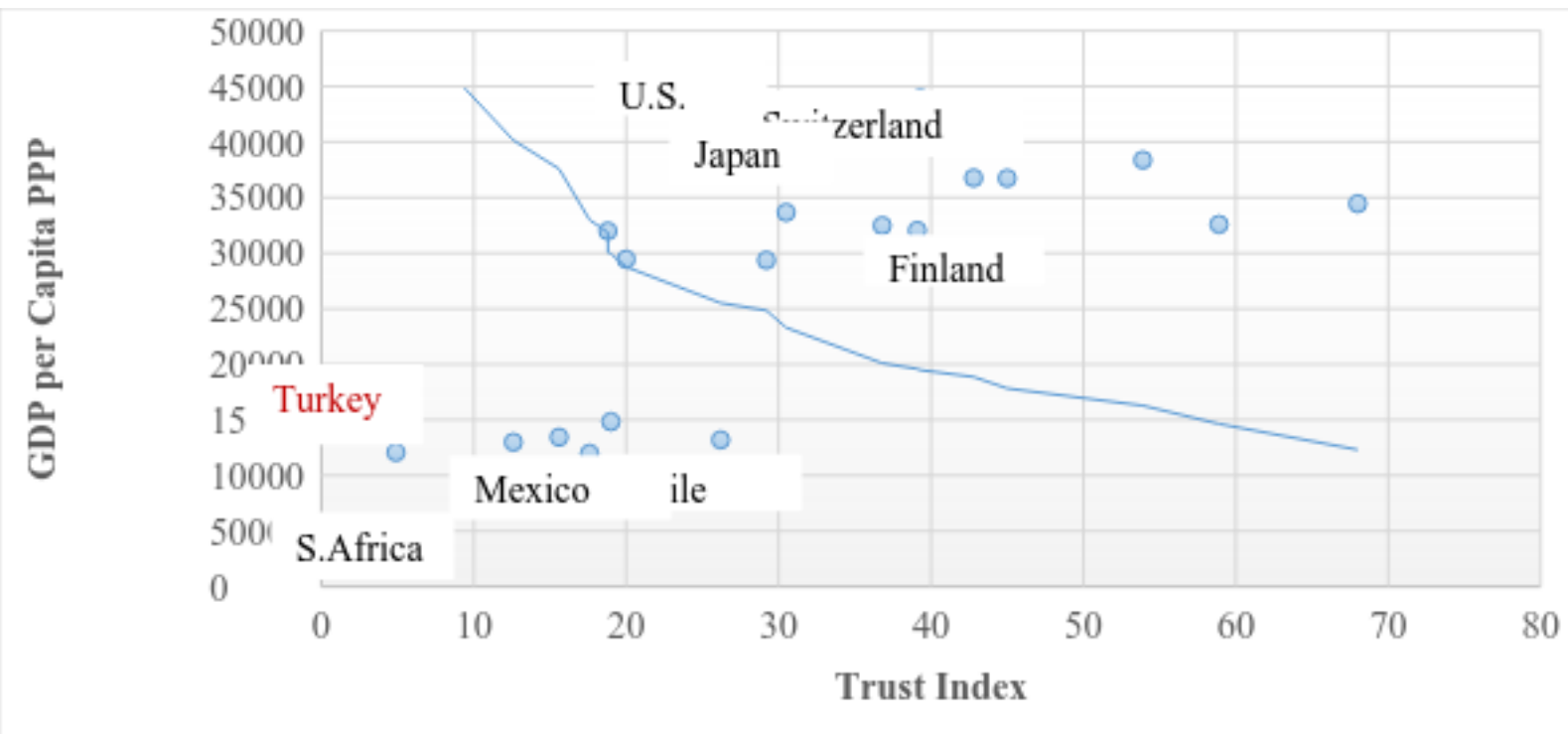

Source: UNDP and WWS 2007

Figure VII demonstrates the relation between trust and GDP per capita in selected OECD countries. As seen in the graph, there is a positive correlation between these two variables across countries. While the trust index is relatively higher in Nordic countries, as is the GDP per capita, and it is lower in countries such as Turkey and Brazil, as is the GDP per capita.

${ }^{25}$ Statman M., at all., "Countries and Culture in Behavioral Finance”, CFA Institute, September 2008 


\section{CONCLUSION}

Although saving rates in an economy is determined by numerous factors, such as demographics factors, economic factors as well as institutional factors, the role of the institutions is extremely critical for savings rates in an economy and so, economic growth.

In the case of Turkey, despite of the fact that the role of financial system is incontrovertible in determining the savings, the role of culture should also be considered as one of the determinants of savings rates since it has direct or indirect impact on almost all variables determining saving rates. In fact, considered the relatively lower LFPR for females and the lower trust index in Turkey, we may infer by looking at these two variables that cultural structure has an important impact on saving rates in Turkey.

The relatively low savings rate in Turkish Economy reveals that the Turkish economy needs some measures to increase this lower rate. However, while some of these measures should be taken in the short-run, some should not, as in the case of cultural structure. Since there is a historic background in forming cultural structure, it may take time to change the culture, and it may be impossible to change some cultural habits by policies. Accordingly, the Turkish economy may 1) develop new financial instruments that both attract investors who currently save in the form of "gold under the mattress" (111.7 billion USD value according to one estimation ${ }^{26}$ ) and other potential investors or 2 ) improve the current financial system to encourage households to save more, for example, by redesigning the tax system or pension system to favor more savings, or both.

\footnotetext{
${ }^{26}$ Kucuksarac, D., Ozel, O., Ucarkaya, S., ‘'Turkey’s Net Foreign Exchange Position’, Central Bank of Turkey Economy Notes, 2012
} 
Yönetim ve Ekonomi Araștırmaları Dergisi / Journal of Management and Economics Research

Cilt/Volume: 15 Sayı/Issue: Özel Sayı 1/Special Issue 1 Aralık/December 2017 ss./pp. 125-143

H. Tekin Doi: http://dx.doi.org/10.11611/yead.373771

\section{REFERENCES}

Acemoglu D., Jonson S., Robinson J. (2001), “The Colonial Origins of Comparative development: An Empirical Investigation" American Economic Association

Aktug R., (2010) "Public Pension in Turkey: Reforming the System to Achieve Fiscal Balance", Perspectives on Business \& Economics, Volume 28

Alesina, A., and Nicola Fuchs-Schündeln. (2007). "Goodbye Lenin (or Not?): The Effect of Communism on People." American Economic Review, 97(4): 1507-1528.

Algan Y. \& Cahuc P., (2013). "Trust, Growth and Well-being: New Evidence and Policy Implications," IZA Discussion Papers 7464, Institute for the Study of Labor (IZA).

S., Filiztekin A., Pamuk S. (2007), "The Sources of Long-term Economic Growth for Turkey, 18802005”, CEPR Discussion Paper Series

Antecol H. (2000), “An Examination of cross-country differences in the gender gap in labor force participation rate", Labor Economics 7, February

Beck T, Webb I. (2003), “Economic, Demographic, and Institutional Determinants of Life Insurance Consumption across Countries", the World Bank

Cooray A., Potrafke N. (2001), “Gender Inequality in education: Political institutions or culture and religion?" Konstanz Working Paper, University of Konstanz

Fernandez R. (2007), “Alfred Marshall Lecture Women, Work and Culture”, Journal of the European Economic Association

Fernandez R. (2010), “Does Culture Matter” Discussion Paper Series, Leibniz Information Center for Economics

Ferruci G.i, Miralles C. (2007), "Saving Behavior and Global Imbalances: The role of emerging market economies" European Central Bank Working Paper Series No 842

Flora M.S. (2004), "Does Gender have any effect on aggregate saving? An empirical analyses", American University, Washington

Gorodnichenko Y., Roland G., (2010) "Culture, Institutions and the Wealth of Nations", IZA Discussion Paper

Guiso L., Sapienza P., (2005), “Trusting the Stock Market” CFS Working Paper 
Yönetim ve Ekonomi Araștırmaları Dergisi / Journal of Management and Economics Research

Cilt/Volume: 15 Sayı/Issue: Özel Sayı 1/Special Issue 1 Aralık/December 2017 ss./pp. 125-143

H. Tekin Doi: http://dx.doi.org/10.11611/yead.373771

Greif A. (2006), "Institutions and the Path to the Modern Economy: Lesson from Medieval Trade" Cambridge University Press

Guiso L., Sapienza P., Zingales L. (2005), “Does Culture Affect Economic Outcomes?” The Journal of Economic Perspectives,

Henrekson M. (2007), “Entrepreneurship and Institutions” IFN Working Paper No: 707

Herger N., Hodler R., Lobsiger M. (2007), "What Determines Financial Development? Culture Institutions or Trade", World Trade Institute

Hunt M., "Race/Ethnicity and Beliefs about wealth and Poverty" Northeastern University

James P. J. (1998), “Culture, freedom and economic growth: Do cultural values explain economic growth?” Journal of World Business Volume 33, Issue 4, Pages 332-356

Joulfaian D., Richardson D.P., (2001), “Who Takes Advantage of Tax-Deferred Saving Programs?

Evidence from Federal Income Tax Data”, National Tax Journal, Vol. 54, No. 3, Pp. 669-88

Kalemli-Ozcan S. (2007), "Financial Development, Institutions, and Growth: Historical evidence from Ottoman Empire", University of Huston and NBER

Kim S-K., (1997), "Class Struggle or Family Struggle? The Lives of Women Factory Workers in South Korea", Cambridge University Press

Kucuksarac, D., Ozel, O., Ucarkaya, S. (2012), ‘'Turkey’s Net Foreign Exchange Position’, Central Bank of Turkey Economy Notes, 2012

Leibfritz W. (2009), "Reducing Undeclared Work in Turkey-The Role of Tax Policy and Administration", Background Paper for Country Economic Memorandum prepared for the World Bank

Leibniz Information Center, "Culture and Institutions: economic development in the regions of Europe" CESifo working papers, No. 1492

Loayza N., Schmidt-Hebbel K., Serven L. (2009), "What Drives Private Saving Across the World" Central Bank of Chile, Working Papers

Matur E., Sabuncu A., Bahceci S., "Determinants of private savings and interaction between public\&private savings in Turkey"

Muradoglu G., Taskin F. (1996), "Differences in Household Savings Behavior: Evidence from Industrial and Developing Countries" The Developing Economies 
Yönetim ve Ekonomi Araștırmaları Dergisi / Journal of Management and Economics Research

Cilt/Volume: 15 Sayı/Issue: Özel Sayı 1/Special Issue 1 Aralık/December 2017 ss./pp. 125-143 H. Tekin Doi: http://dx.doi.org/10.11611/yead.373771

Nosal E., Rupert P. (2002), "Infrastructure and the Wealth of Nations" Federal Reserve Bank of Cleveland

Rodrik D. (1997), “TFPG Controversies, Institutions, and Economic Performance in East Asia”, NBER Working Paper Series, Cambridge

Shafir E., Mullainnathan S. (2009), "Savings Policy and Decision-making in Low-Income Households", Innovation for Poverty Action

Sheeraden M., Schreiner L., Beverly S. (2003), "Income, Institutions, and Saving Performance in Individual Development Accounts", Economic Development Quarterly

Shoham A., Vrontis D. (2012), "The role of cultural attributes in savings rates", Cross Cultural Management, 304-314

Statman M., at all. (2008) "Countries and Culture in Behavioral Finance”, CFA Institute

Thaler R., Benartzi S. (2004), "Save More Tomorrow: Using Behavioral Economics to Increase Employee Saving”, Journal of political Economy, vol.112, no. 1 pt.2

The World Bank (2011), "Sustaining High Growth: The role of domestic savings" Turkey CEM

Uygur E., "Domestic savings in Turkey: Policy, Institutional and Legislative Framework" Background paper for Country Economic Memorandum (CEM) Sustaining High Growth: The Role of Domestic Savings

Vittas D., Skully M. (1991), “Overview of Contractual Savings Institutions”, the World Bank

Wilkinson B. (1996), "Culture, Institutions and Business in East Asia", European Group for Organizational Studies, 17:421

Zee H., Tanzi V. (1998), “Taxation and Household Saving Rate: Evidence from OECD countries”, IMF Working Paper

www.turkstat.gov.tr accessed on October 20, 2013

www.tcmb.gov.tr, www.borsaistanbul.com accessed November 23, 2013

http://www.dpt.gov.tr/, accessed on October 2, 2013

http://www.hazine.gow.tr/, accessed on October 2, 2013

http://www.gib.gov.tr/index.php?id=469 accessed November 23, 2013

http://www.merriam-webster.com/, accessed on December 2, 2013

http://www.turkstat.gov.tr/, accessed on October 2, 2013 
Yönetim ve Ekonomi Araștırmaları Dergisi / Journal of Management and Economics Research Cilt/Volume: 15 Sayı/Issue: Özel Sayı 1/Special Issue 1 Aralık/December 2017 ss./pp. 125-143 H. Tekin Doi: http://dx.doi.org/10.11611/yead.373771

ttp://www.bddk.org.tr/WebSitesi/turkce/Raporlar/TBSGG/12277tbs_genel_gorunumu_haziran_2013. pd, accessed on October 2, 2013

http://www.worldbank.org, accessed on October 2, 2013 